\title{
Public Sector Responsiveness in the Strategic Environment Change:
}

\author{
A Case Study of Indonesian Bureaucracy in Response to Internal Governance Change
}

\author{
Benedicta Retna Cahyarini*, Ladiatno Samsara \\ National Institute of Public Administration of Republic of Indonesia \\ Jakarta, Indonesia \\ *benedicta.retna@gmail.com
}

\begin{abstract}
Due to the Covid-19 outbreak, Indonesian government assign its civil servants from the high transmission rate area to work from home. Consequently, the bureaucracy sector needs to encourage the utilization of information technology. However, with the new digital environment, other challenges need to be solved by Indonesian public sector, for instance, the lack of digital competency among civil servants, manual working arrangement and inadequate infrastructure to support the digital environment. Therefore, this study wants to answer the question about what the Indonesian public sector should do to manage the internal governance affair to show their responsiveness in answering the strategic environment change. The study aims to give the holistic picture of the problem faced by the public sector in strategic environment change due to Covid-19 pandemic which force them to apply digitalization in the day-to-day business. Moreover, in this study, researcher provide the solution on how the bureaucracy sector should respond to the utilization of digital environment through competencies developments, new working arrangements and infrastructure improvement. Descriptive qualitative method is conducted in this study to generate research result. Data are collected and analyzed using desk study review of various literature, news, government legislation, report and a direct observation of Indonesian civil servants' daily tasks. As a result, the study found that the public sector's effort in response to the internal governance rapid change is not enough. Therefore, the Indonesian government need to change some of the regulations related to working hours, key performance indicator, and performance assessment that supporting digital environment.
\end{abstract}

Keywords-competencies development, digital environment, digital competency, working arrangement, public sector responsiveness

\section{INTRODUCTION}

Covid-19 pandemic affects daily social life. For example, we are more familiar with the term "lockdown" that refers to the policy to close the borders or carry out regional quarantine for a certain period to reduce the virus transmission rate. When the Covid-19 hit Indonesia in March 2020, the Indonesian government implement lockdown strategy in a more flexible way with the term of large-scale social restriction. This policy has taken to cut the virus spread by restraining people's movement. This policy followed by restriction of business activities from both the private and public sectors. Companies and organizations assign their employees to move from working from the office to working from home (WHF). This means, the working arrangement change from conventional working to a remote working arrangement. The decision of WFH implementation regulate in Circular Letter of Ministry of Administrative and Bureaucratic Reform Republic of Indonesia number 19 the year of 2020 .

The discourse of WFH has become a discussion in the government sector in the last few years. Moreover, the concept of flexible working arrangement (FWA) is prepared and ready to implement. But the plan never comes to light, the government seems hesitant to carry out this policy. However, since the first case of Covid-19 found in Jakarta, the Indonesian government does not have any choices. The Indonesian government forced government agencies located in the capital city.

Prior to the Covid-19 outbreak, the Indonesian government is not so familiar with the technology utilization that shows in their conventional working system in the bureaucracy. On the other hand, technology utilization in the private sector has become an organizational urgency. The new working arrangement gives a positive impact on the bureaucracy. WFH encourage the government sector to be more adaptive in term of the digital environment. Consider that government employees work from their home, every tasks and communication done by digital technology utilization. For example, the using of online meeting application, digital source document, and e-validation document.

Nonetheless, the digitalization change is unfollowed by the related regulation in the public sector's management. The government need some time to make a transition from one circumstance to another. Thus, the public sector needs to encourage regulation flexibility to respond to the uncertainty in the strategic environment. Moreover, from the government employees' side, WFH arrangement requires them to change from conventional to digital-based working system. The 
problem appears when there is a lack of digital competency among civil servants and inadequate technology devices belong to them.

Therefore, this paper wants to answer the question about what the Indonesia government should do to manage the internal governance affair to show their responsiveness in answering the strategic environment change. The purpose of this study is to give the holistic picture of the problem faced by the public sector in strategic environment change due to Covid19 pandemic which force them to apply digitalization in the day to day business. Moreover, in this study researcher wants to provide the solution on how the bureaucracy sector should respond to the utilization of digital environment through competencies developments, new working arrangements and infrastructure improvement.

\section{LITERATURE REVIEW}

\section{A. Government Responsiveness}

Responsiveness only exists if there were a response from the second party to the demand from first party [1]. In other words, there has to be supply and demand between parties. Thus, in the public administration area, responsiveness is described as the effort from the government agency to provide fast and helpful service to the public [2]. Added by Friedman, to show their level of responsiveness, government agencies should be cooperative and respectful to the public as their clients [2]. Another researcher said that government responsiveness is consist of two factors: government sensibility and government ability to solve the problem [3].

First, in term of government sensibility, as mentioned in the study, there are five principles in the first factor, namely: access, choice, information, representation and improvement [3]. Nurani et al. [3] describe access as the approachable service provided by the government for the public. Choice refers to different service from the government that allows people to chose depends on what they need. Next is information to increase the shared responsibility between the public and government to improve public services [3]. The information principle is related to improvement as the next principle. As mentioned by Nurani et. al [3], the improvement is needed to fulfil the public demand. Therefore, to improve the public services, communication among society and between society and government is an important key to better public service. The last principle is the representation that refers to society involvement and collaboration in the public service policy making and practices [3].

The second factor in government responsiveness is the ability. Nurani et al. said that the government ability to be responsible is presented in their willingness to draw government regulation [3]. As argued by Nurani et al., providing regulation to solving the problem or to answer the society need is considering as the government responsiveness [3].

\section{B. Digital Competency}

Digital competency is needed in every organization both in the public and private sector, even in the traditional industry [4]. However, not all the organization ready to implement this digital transformation. In the public sector, digital transformation becomes an issue in the last five to ten years. But not many of them take the challenge to implement digitalization in the public sector. However, technology utilization is believed as an important factor to improve public services. Due to the Covid-19 pandemic, the public sector all over the world is challenged to implement technology utilization and moving towards the digital government implementation phase. Unlike e-government that focus on efficiency and transparency through digitalization, digital government require integration in the digital system to improve public services [5]. Consequently, to follow the demand from the digital government implementation, the civil servant digital competency is crucial to improve.

Digital competency refers to the skills to access the internet, data collecting and sharing and require knowledge, attitudes, abilities, strategies and awareness, that will create thoughtful and healthy use of technology [6,7]. There are three dimensions in the digital competency, first is the technological dimension that refers to the ability to receive and explore something new; second is the ethical dimension that related to the responsible use of technology; and third is the cognitive dimension that describes how we use our skills to access, choose and interpret data from the internet [4]. Besides, the logical and critical thinking ability is important in digital competency and will determine the information management and communication skills [4]. Hence, concept of digital competency is a pluralistic concept that describes the complex network of purposes, domain and level of technology use [7].

From the explanation above, we can conclude that digital government require highly digital competency from both government employees and society. This can be a serious problem because digital competency often considers as younger people's competency. Some study from the British Computer Society found that only $52 \%$ of employers believe that their employees are well enough in term of digital skills [4]. Digital competency has also become a problem form the Indonesian government. As a response to the Covid-19 outbreak, the government pushing the use of technology to their employees. Although we have not considered this practice as a digital government implementation, we can say that the digitalization in the Indonesian public sector is one good move towards Indonesian digital government implementation.

\section{Working Hours and Performance Appraissal for Indonesian Government Employees}

The Decree of the President of the Republic of Indonesia number 68 the year 1995 regulate the working days in the Indonesian government agencies. The regulation says that the Indonesian civil servant works five days a week from Monday to Friday [8]. Base on this regulation, civil servant required to work 7.5 hours per day or 37.5 hours per week [8]. The 
working hours arrangement base on The Decree of President of the Republic of Indonesia affects the civil servant performance appraisal. In the performance appraisal, the manager looking through the performance achievement and the civil servant working hours, whether the civil servant obeys the working hours regulation. Since regulated in 1995, the Decree of the President of the Republic of Indonesia number 68 the year 1995 has not been amended.

Regarding the performance appraisal, the Indonesian government regulate the performance evaluation through Government Regulation of the Republic of Indonesia Number 30 the year 2019. The performance appraisal aims to ensure the merit of civil servant career development [9]. The regulation rules the civil servant performance management system. The system is consists performance systematic process from planning, activities, monitoring and performance coaching, performance assessment and follow up, and also performance information system [9]. The civil servant set the yearly key performance indicator (KPI) that consist of performance plans and targets. Based on the KPI, the performance assessment executed by the manager regarding the performance targets, performance achievements, work result and benefit as well as government employee's behavior.

\section{Methodology}

The descriptive qualitative method conducted in this study. This method helped the researcher to describe the benefit and obstacle of the digitalization in the public sector. As a result of the description, the researcher is able to offer solutions on how the government sector should respond to the strategic environment change through digitalization.

Data gathered from secondary data and direct observation in term of strategic environment change and government digitalization in the Indonesian public sector. A desk study carried out from different kinds of literature, books, journals, articles, news, and government regulations related to the research topic.

\section{DISCUSSION AND ANALYSIS}

The WFH policy is an innovative policy implemented by the Indonesian public sector to minimalize the covid-19 virus spread. Moreover, it can be seen as a pilot project to implement Flexible Working Arrangement (FWA) which has been a discussion subject in the last few years. Since the first case of Covid-19 revealed, the Indonesian government take a quick move to implement WFH policy. In this case, it can be seen that the public sector starts to be adaptive to the strategic environment dynamic. Heifets said that the kay of adaptive leadership is the leader's ability to change the circumstances [10]. Furthermore, there are two factors in the government responsiveness concept, government sensibility and government ability to solve the problem. As mentioned in the literature review, the government sensibility factor refers to access, choice, information and representation [3]. Regarding the WFH policy implementation, those five principles in the government sensibility factor are fully accommodated since the government open the opportunity for their civil servants to do the job task from home.

However, the implementation of FWA will reshape the whole working arrangement system in Indonesian bureaucracy because it opens the opportunity for the civil servants to work remotely. Since the implementation of WFH is a response to the Covid-19 outbreak, but it is not impossible to promote this policy as a permanent policy in the future. Thus, starting in this phase, the Indonesian government need to be aware of another prerequisite detail such as working arrangement regulations including working hours and employees' performance, competency development and digital infrastructure improvement.

\section{A. Working Hours Formalization in the WFH System}

The implementation of the WFH system is interpreted as moving the working place form office to home and work according to office working hours. The civil servant must work at least seven (7) hours a day and proven in the digital presence system and will determine the performance evaluation and salary. Clearly, the WHF practice is far from FWA concept which allows the working hour flexibility. Thus, it can be concluded that WFH policy that is already implemented for more than six months, is not followed by working hour flexibility regulation.

A survey conducted by the Ministry of Administrative and Bureaucratic Reform report that overtime work during the WFH $46 \%$ of respondent work three to four hours more than the office hour time [11]. In addition, from the direct observation, civil servants said that sometimes they have to attend online meeting after work hours without additional incentive or overtime pay mechanism.

\section{B. Job Bias and Working Performance}

Based on researchers' observation, WFH cannot be applied in every job position, depends on the nature of the job position. Several job positions must do their tasks at the office. Therefore, the public sector does not have the job position evaluation to identify the nature of work tasks. As a consequence, there is unclear performance evaluation during the WFH policy implementation. Some of the government employees have flexible job character in term of time and place. In this kind of job, they can achieve performance targets easily by working from home. On the other hand, there is some office characteristic's job, so the staff found it difficult to achieve higher performance during WFH. Those unfortunate phenomena happen because the Indonesian civil servant's performance appraisal regulation is drawn based on job office characteristic. Performance assessment for remote working based on output is not yet included in the Government Regulation No 30/2019 that regulate the Indonesian civil servant performance appraisal.

Performance-based output already used to evaluate certain job position in government employees (specialist employee 
such as researcher, lecturer, doctor, teacher etc.). For specialist staff position, KPI is related to their career's credit points. But, in the Indonesian public sector, most of the employees are in the administrative staff position with office-based tasks. With the implementation of WFH, the administrative staff position found problems in doing their daily tasks, even to meet with their performance targets. Thus, the implementation of WFH is not yet followed directly with the new regulation in the performance evaluation system. Therefore, this makes the change in the performance appraisal system the second issue that needs to be addressed immediately.

\section{Indonesian Civil Servant's Individual Competency}

Individual competency is important to achieve organizational goals and performance. Competency described as a capability to use knowledge, skills, and abilities that required to perform tasks from the designated work setting [12].

Refer to National Institute of Public Administration of Republic of Indonesia (NIPA RI) Regulation No 10 the year of 2018, the civil servant competency is defined as civil servant's knowledge, skills, and attitude or behavior that can be observed, measured and developed in a job assignment [13]. In the NIPA RI Regulation No 10 the year of 2018, there are 3 different types of competency: (1) managerial competency which refers to leading and managing organizational unit; (2) technical competency that related to competency in the area of expertise or job position; (3) social-cultural competency that refers to the competency related to the interaction experience in the pluralistic society in terms of ethnicity, religion, culture, behavior, the insight of nationality, ethics, values, moral and principles. Those three competencies are mandatory for all civil servants based on each job position.

In addition, technical competency is divided into another three terms, i.e. general competency, administrative competency and area of expertise competency. The general competency is mandatory for every civil servant, such as using a computer to do the task and communication capability. Administrative competency related to administrative task such as correspondences, financial and budgeting system. While the area of expertise competency is related to the specific business area depends on the civil servant's job position, for example, research competency, health competency, competency in the nuclear sector.

Since the implementation of WFH, there is some development in the general competency, particularly in the digital competency. The digital competency is a prerequisite of the WFH policy implementation. Digital competency has three dimensions as a foundation: technical dimension, ethical dimension and cognitive dimension. However, there is an uneven digital competency distribution among Indonesian government employees. Based on data from Ministry of National Development Planning of the Republic of Indonesia, only $46 \%$ from 4.286 .918 total Indonesian civil servants are understood about digital technology, whereas the rest $(56 \%)$ said that they do not know about technology [14]. It means that more than half of the government employees experienced a lack of digital competency.

The lack of digital competency is a consequence of the inadequate digital devices belong to the government employees. The majority of the civil servant do not have adequate digital technology devices except mobile phone. The other digital equipment, such as a computer, laptop, tablets are very luxurious devices for most of them. Therefore, the implementation of WFH could not run effectively.

\section{Individual Performance}

In the Indonesian government agencies, employee's performance measured using Key Performance Indicator (KPI) and employee's presence. KPI contains employee's tasks and targets in details, while the employee's presence is to measure the daily attendance whether the employee fulfils the designated working hours. However, the civil servant performance evaluation based on KPI and attendance is no longer fits with the new working arrangement due to Covid-19 outbreak. In the WFH implementation, performance evaluation only possible to carry out through employee's target achievement. So, it needs some adjustment in the KPI document to accommodate the implementation of WFH. KPI document consists of year task and target performance. Thus, in the WFH implementation, the daily tasks in details need to be included in the KPI. This need to be done to measure the civil servant's daily achievement. However, the daily performance evaluation seems not easy to execute, since the public sector's job description varies in term of time and works standard. For instance, correspondence tasks that can be done daily and weekly or monthly report. Those three have different time completion and work standards. Therefore, to be able to implement WFH effectively, performance evaluation based on daily target is needed for performance appraisal objectiveness.

\section{RECOMMENDATION AND CONCLUSION}

Work from home (WFH) policy for Indonesian civil servant applied as one of the strategies to prevent the Covid-19' massive transmission. However, assigning the employees to work from home instead of work from the office is a rather tricky policy. The government also need to response the implication of WFH from the internal side particularly in the working arrangement and performance evaluation. Therefore, the Indonesian government need to change some of the regulations related to working hours, key performance indicator, and performance assessment that support digital environment. Thus, this paper recommends for the Indonesian government to take action in order to follow the strategic environment change:

- To improve civil servant digital competency

- Change the working environment from working hours based to output based.

- Encourage the daily activity output in the KPI. 
- Strengthen the digital environment in the government agencies.

Besides, this paper would like to suggest the next research agendas to support this paper result:

- The analysis to change the working hours based to performance base.

- The analysis of daily output based KPI including reward and incentive.

\section{REFERENCES}

[1] R. Avidar, "The responsiveness pyramid: Embedding responsiveness and interactivity into public relations theory," Public Relat. Rev., vol. 39, no. 5, pp. 440-450, 2013.

[2] B. D. Friedman, Responsiveness, 2009, [Online] Retrieved from: http://faculty.ung.edu/bfriedman/Studies/respon.htm.

[3] A. S. Nurani, S. Zauhar, and C. Saleh, "Responsivitas pemerintah dalam penyelenggaraan pendidikan inklusif dalam perspektif new public service," Wacana, J. Sos. dan Hum., vol. 18, no. 04, pp. 213-220, 2015,

[4] Z. Nyikes, "Contemporary digital competency review," Interdiscip. Descr. Complex Syst., vol. 16, no. 1, pp. 124-131, 2018.

[5] OECD, "Digital Government Index: 2019 results," OECD Public Gov. Policy Pap., no. 3, p. 68, 2020.
[6] A. Ferrari, Y. Punie, and C. Redecker, "Understanding digital competence in the 21st century," pp. 79-92, 2012. in press

[7] J. Janssen, S. Stoyanov, A. Ferrari, Y. Punie, K. Pannekeet, and P. Sloep, "Experts' views on digital competence: Commonalities and differences," Comput. Educ., vol. 68, pp. 473-481, 2013.

[8] The Indonesian Govenment, Keputusan Presiden Republik Indonesia No.68 tahun 1995 tentang Hari kerja di lingkungan lembaga pemerintah. 1995

[9] The Indonesian Government, Peraturan Pemerintah No 30 tahun 2019 tentang Penilaian kinerja Pegawai Negeri Sipil. Republik Indonesia, 2019.

[10] C. M. Simamora, Pemimpin perubahan (adaptive leader), 2018, [Online] retrieved from: http://pusdiklat.kemendag.go.id/v2019/news/pemimpinperubahan-adaptive-leader

[11] Ministry of Adiministrative and Bureaucracy Reform Republic of Indonesia, "Arah kebijakan manejemen ASN di masa pandemic covid19 dalam rangka mendukung performa kinerja pemerintah,” 2020. Presentation. unpublished.

[12] Govenrment of Western Australian, What is competency and how is it assessed?, [Online] retrieved from: https://www.dmp.wa.gov.au/Safety/What-is-competency-and-how-is-it5973.aspx

[13] National Institute of Public Administration of Republic of Indonesia, Peraturan Lembaga Administrasi Negara Republik Indonesia Nomor 10 Tahun 2018 Tentang Pedoman pengembangan kompetensi pegawai negeri sipil. 2018.

[14] R. R. Wrihatnolo, "Tantangan aparatur negara dalam era transfromasi digital," Jakarta, 2020. 